\title{
Who Is Confronting Whom? Conflicts About Renewable Energy Installations in Germany
}

\author{
Gerhard Fuchs \\ University of Stuttgart
}

The electricity transition in Germany has always been a contentious issue. Since the end of the second decade of the new millennium, the impression arises that the main debate is between interests of society on the one hand and local or regional opposition on the other hand. Even research organizations for some years spent a lot of effort studying the question, whether the electricity transition lacks acceptance in the population, at least in areas in which new installations (especially) wind and power grids are being built. As such, protest activities have become an eminent political as well as practical problem. The present article analyzes four selected siting conflicts in order to show that these conflicts are not one-dimensional. A variety of actors from different fields are participating, with different aims and using different framing strategies. Both theoretically as well as empirically, it seems difficult to locate interests of the society as opposed to interests of local or regional communities. Both local as well as societal interests are not uniform and stable. Conflicts should be treated as situated in a four-dimensional space in which social, topical, temporal and spatial aspects intermingle.

Keywords: electricity transition, civil society actors, conflicts

\section{INTRODUCTION}

For some time the German energy transition was looked upon as a role model, as a forerunner example for a potentially successful large scale electricity transition. Meanwhile the euphoria has passed and other countries seem to have moved ahead in their transition experiences. One characteristic element of the German transition has been its contentious character. This does not want to say that there was public opposition against the transition. Quite to the contrary: if we believe in opinion poll data there was and still is a consistent large majority among the population in favor of abandoning nuclear energy as well as fossil fuels and an overwhelming support for renewable energies. The transition, nevertheless, has over the last thirty years been a topic of constant debate. The participants in this debate, however, have changed; the leading topics have changed as well as the aims pursued by the concerned actors. If we want to study and understand conflicts related to the transition, we cannot treat them as isolated events, but we have to see them as a part of an evolving transition pathway.

This article will try to sketch out this theme in some more detail. It will do the following: (1) it will develop a relational analytical perspective on the development of renewable energy installations and (2) will analyze different types of spatially situated conflicts about the siting of renewable energy installations in Germany to illustrate the chosen analytical perspective. 
As Niklas Luhmann [1] has argued, all social actions have a spatial, social, temporal and topical aspect. All social action is somewhat spatially situated, but the relations between spatial, social, temporal and topical aspects are varying. None, of course, can be isolated from the other ones. Usually social aspects trump aspects of space or physical proximity. There are some exceptions to this, e.g., persons who are living close together have a higher probability to meet, even if the social distance between them is great. Spatial aspects and material aspects intermingle in an especially interesting manner, when we look at siting conflicts. The nature around us means different things to different people. In a recent conflict about the question what to do with a huge area of land that for economic reasons was not used any longer for agricultural exploits, different options were voiced: Some wanted to preserve nature as an open field, some wanted to install solar panels on the open fields and still another group wanted to pour concrete all over the place and turn it into a major industrial storage area. In this case, the third option won. While some argued that solar panels would destroy the traditional image of how we look at nature, the building of concrete walls around the new storage facilities won because of economic reasons. People react towards nature, but nature does not have the qualities of a meaningful acting person (other than I as an observer grant nature or whatever else there might be these qualities and with my profound knowledge of what things want, explains this to the other observers; the observed stuff will remain silent.) It is part of a relation that becomes established in social interaction and which eventually will create new relations.

The article will analyze four different types of conflicts in which the relationship between social, spatial, temporal and topical aspects plays out differently: two conflicts about wind energy installations, one concerning grid extension and one involving a biomass installation (section six). Before discussing the empirical examples, we will start out with presenting our relational perspective (section two). This will be followed by some general remarks concerning the contentious character of the German transition pathway (section three). The argument will be discussed and summarized in section seven.

\section{WHAT IS A RELATIONAL PERSPECTIVE?}

Relational perspectives recently have become more widespread in many disciplines. The present article starts from a sociological perspective [2]. Sociology in the tradition of Max Weber [3] is about social actions, interactions, in which at least two individuals are participating. It is not required that they are physically co-present, but the actions need to be addressed to another person and the expectations of this actor are taken under consideration. This need also not be in a harmonious way, as Parsons suggested in his famous assumption, which form the corner stone of his systems theory. "An established state of a social system is a process of complementary interaction of two or more individual actors in which each conforms with the expectation of the other(s) in such a way that the alter's reaction to ego's actions are positive sanctions which serve to reinforce his given need-dispositions and thus to fulfill his given expectations." [4] (p. 205). To the contrary: interactions might be friendly, unfriendly, surprising, habitual etc. depending on the specific situational context. All these interactions are of course "local" one's, insofar as they are established at a given point in time by identifiable actors.

Spatial proximity might play a role in this, but what role exactly, is difficult to say. As various studies have shown, spatial proximity does increase the probability of persons to interact, even if they are not socially close to one another. As Watts [5] (p. 133) has argued, it seems highly likely that interpersonal relations will be affected by distance in two spaces, geographic space and social space. However, precisely because two different spaces are involved, we cannot describe the formation of interactions by embedding all persons in a single analytical space and predicting that those close will form relationships.

Of major importance at any rate are the interactions between actors and the field within which these interactions take place. As Karl Marx has noted: history is made by actors, but under circumstances that are not chosen by them. "Men make their own history, but they do not make it as they please; they do not make it under self-selected circumstances, but under circumstances existing already, given and transmitted from the past." [6]. Society is a web of crystallized interactions. While there is no society as a thing in itself but only persons and their actions, these interactions themselves have a tendency to reify, to become thinglike, and even may guide spontaneous action. Society then can be seen as the set of permanent interactions 
"crystallized as definable, consistent structures." [7] (p. 9f.) or again in the words of Karl Marx "Society does not consist of individuals but expresses the sum of interrelations, the relations within which these individuals stand." [8]. Interestingly in this case there is some agreement with the position of systems theory as interpreted by Luhmann. Luhmann also claims that society as such cannot act [9] (p. 802). We know nothing about actors and goals. Society does not have an essence [9] (p.89), no address [9] (p. 866), no purpose [9] (p. 818).

Without intending to jump ahead, I am just making this point, because in the literature we often find a discussion about why citizens protest against renewable energy installations, which they should in principle approve of. A tension is seen to be existing between the legitimate demands of society and the individual as well as group interests or a line of conflict is constructed between citizens and "the state". Both the state and society are not acting. For example, many analyses of the relation between the state and challengers (such as citizen actions groups, social movements etc.) assume that states (or societies) are actors. They therefore imagine that the state, confronted an opponent, and, mindful of its own interests and resources, took actions that were most likely to allow the state, as state, to realize its goals. This is untrue, and leads to error. Specific individuals do the acting. Sometimes they valiantly attempt to be mere agents of something else, but even then, it is quite rare that it is clear to impartial analysts, or even to the actors themselves, whom they represent (The state? The government? The nation? Their party? The voters? Those who voted for them? Their protectors? Their immediate supervisors? And so on). More generally, states are assemblages of actors pursuing their own goals at the same time, as they are responsible to other claimants. McAdam/Schaffer Boudet [10] in their analyses have pointed out that the non-uniform character of the public administration in fact is an important asset for protest movements. Parts of the public administration or political bodies might support opposition, while others do not. Thus, it is important to untangle the actor state or the public or society into those units, which are engaged in the specific conflict under study.

\section{DIMENSIONS OF SOCIAL INTERACTION AND SITING CONFLICTS}

It is not the intention to discuss Luhmann's systems theory in this article, especially because we gather the theory as such is not very helpful in explaining the electricity transition in Germany - especially from a practical point of view. Nevertheless, we take from his oeuvre the notion that social interaction has different dimensions, which can be loosely differentiated between a temporal, topical, social and spatial one.

With respect to the temporal dimension, we are not so much interested in looking at the length of the siting conflicts, not only because it is sometimes very difficult to analytically isolate "the" conflict. Usually the conflicts are embedded in a longer history of disputes and contentious events. Thus, we will be primarily looking at the overall development of the German electricity transition. Doing this, we will be distinguishing between four phases, which signal that the overall framework within which protest activities have taken place has changed over time. Organizing and mobilization takes place at specific points in time. The history of renewable energy installations in Germany now dates back to the early 1990s. Protest activities related to renewable energies have to be seen in this temporal context and the changing environment in which renewable energies developed from a challenger technology toward a dominant source for electricity supply. As such, it is obvious that the essence of the conflicts nowadays is essentially different from the ones experienced in the 1990s. When we are analyzing the conflicts, we have to be aware of the changing environment, the history of the struggles, the changing social practices [11].

The topical dimension deals with the problem what the conflict is all about. With this, we refer to the actual demands that are voiced. The topical dimension is linked to the temporal one. In the 1990s, the main issue was to experiment with new ways of generating and distributing electricity in order to have an alternative to nuclear energy and fossil fuels. Electricity generation and distribution was supposed to be done in a decentralized manner and close to the consumer. Meanwhile the federal government has declared that renewable energies will become the main source of electricity generation by 2050 . The big actors (old and new) are now developing sites for mainly economic reasons. In some cases, the Not In My Backyard 
(NIMBY) problem is discussed [12], or the Not In Anyone's Backyard (NIABY) [13] attitude as well as elements of institutional inertia, which make it difficult to change established routines.

The social dimension relates to the actors participating in the conflicts and their positioning. This is again linked to the historical development, but of course not in a uniform manner. We can safely assume that initial efforts for building renewable energy-installations were developed and driven forward by locally based actors - at least in Germany. Later on mobilization was driven forward also by external mobilizers, and eventually with becoming big business, external project developers were entering the scene [14].

The spatial dimension relates to the places where installations have been built and the relationship to the landscape in which they are embedded. Protest activities take place in specific places: in cities, in the countryside or whatever. Protest activities relate to this spatial context. Whether it has a significant impact on the outcome of conflicts is open for discussion [15]. In the literature, it often can be read that urban or rural structures hinder as well as facilitate electricity transitions. Such an assessment can be translated into the statement that we are not sure, how and why things are happening out there and the way they do [16]. It is obvious that in places like cities we find manifold structures that are of relevance for transition oriented activities. We cannot assume, however, that there is anything like a primordial city without structures in which actors are free to do anything they would like to. Space is always structured. "The" city does not exist.

In the beginning, activities in the communities were aimed at establishing a new down to earth, more democratic, climate friendly energy system. The problem was to find majorities in the community and to fight the influence of the incumbent actors in the energy field proper. Contracts had to be cancelled, providers had to be switched, new organizations were necessary.

With the stabilization and the spread of renewable energy installations, debates centered more on use issues. In the debates about the selection of sites for renewable energy installations economic interests were competing with interests in preserving or establishing an enjoyable environment (tourism), the loss of agrarian land or nature conservation issues, to name just a few.

Only recently elements of a more general movement against renewable energies can be detected, which is underpinned by the spread of general information to protest groups and attempts to build up state- and nationwide networks. Political support for these groups comes especially from new right wing populist parties, which favor a return to nuclear energy and epitomize a climate change denial attitude.

Insofar it is not justified to say that there is one typical protest constellation or that protests are aiming against renewable energies as such or that there is a conflict between what is good for society and what is considered to be good for the individual (NIMBY-phenomenon). Typical constellations have changed over time, a multi-dimensional approach is necessary for analytical as well as practical purposes (cp. table one).

The empirical basis of the research presented in this article was done (a) in three projects, which were conducted within the framework of the Helmholtz Alliance on Future Energy Infrastructures, financed by the Helmholtz Association, (b) in a project on local innovation impulses, financed by the Federal Ministry of Research and Education and (c) in an independently funded project on the bio-energy village movement in Germany. Methods used in all three projects were document analysis, expert interviews, some statistical evaluations and participant observation. In depth case studies were combined with an analysis of the overall institutional development. 
TABLE 1

DIMENSIONS OF SOCIAL ACTION AND SITING CONFLICTS

\begin{tabular}{|l|l|l|l|}
\hline \multicolumn{4}{|c|}{ Dimensions of Social Action and Siting Conflicts } \\
\hline Temporal & Topical & Social & Spatial \\
\hline $\begin{array}{l}\text { Phase one (1989- } \\
\text { 1998) }\end{array}$ & $\begin{array}{l}\text { Experiments with } \\
\text { electricity generation } \\
\text { and distribution }\end{array}$ & $\begin{array}{l}\text { Local challengers } \\
\text { against incumbent } \\
\text { actors }\end{array}$ & $\begin{array}{l}\text { Urban experiments; } \\
\text { save nature }\end{array}$ \\
\hline $\begin{array}{l}\text { Phase two (1999- } \\
\text { 2007) }\end{array}$ & $\begin{array}{l}\text { Diffusion of ideas and } \\
\text { experiments }\end{array}$ & $\begin{array}{l}\text { Government, local } \\
\text { mobilizers and } \\
\text { intermediaries }\end{array}$ & $\begin{array}{l}\text { Local small scale } \\
\text { installations; putting } \\
\text { the local environment } \\
\text { to new uses }\end{array}$ \\
\hline $\begin{array}{l}\text { Phase three (2008- } \\
\text { 2012) }\end{array}$ & $\begin{array}{l}\text { Stop and go, } \\
\text { Institutionalized } \\
\text { opposition against } \\
\text { quick expansion of EE }\end{array}$ & $\begin{array}{l}\text { Government, shake out } \\
\text { of mobilizers }\end{array}$ & $\begin{array}{l}\text { Villages, cities; } \\
\text { competing views on } \\
\text { landscape issues }\end{array}$ \\
\hline $\begin{array}{l}\text { Phase four (2013- } \\
\text { 2017) }\end{array}$ & Managed growth & $\begin{array}{l}\text { Government, } \\
\text { reorganized } \\
\text { "incumbents", project } \\
\text { managers, investment } \\
\text { funds }\end{array}$ & $\begin{array}{l}\text { Nationwide; } \\
\text { industrializing the } \\
\text { landscape }\end{array}$ \\
\hline
\end{tabular}

\section{SOME PRELIMINARY REMARKS ON THE IMPORTANCE OF SITING CONFLICTS}

McAdam/Schaffer-Boudet [10] have noted that the interest of social scientists in cases of conflict may have a distorting effect on the estimation of the overall importance of protest activities. The authors therefore developed a research design that started the analysis not with an actual conflict, but with a siting decision - in this case Liquid Natural Gas (LNG) terminals - and asked in what cases opposition and mobilization happened. They actually found that only in a few cases significant opposition could be observed, thus contradicting the widely held belief that the US would be in the thralls of a movement society creating a hostile environment for investments of various kinds especially infrastructure related ones. However, in cases where opposition was visible and organized, the probability was high that the actual installation was not built. Leaving aside the specific circumstances of LNG terminals, we cannot mimic a similar design for German renewable energy installations, but nevertheless as some kind of a cautionary note we want to hint that even at present the applications to build publicly supported installations like wind mills are by a multitude exceeding the permits that are actually handed out by the authorities. Insofar there is a clear indicator for broad public support. Furthermore, it should be added that in a project that we conducted in which four innovations that were considered by the government to be crucial for achieving the climate policy aims (energy contracting, power to heat coupling, intelligent infrastructures, citizen owned windmills) only wind mills were fulfilling the growth expectations. The other innovations were lacking far behind in realization due to impeding regulatory requirements, difficulties in establishing cooperation between different types of actors, regulatory obstacles that prevent the cooperation of actors after liberalization, entrenched routines, institutional inertia [17]. In the public discussion, however, one gets the impression that the energy transition is constrained by public protests against windmills and solar panels. The other innovations are taking place without much public participation and without much public discussion, but their record of accomplishment is much worse. 


\section{THE GERMAN ELECTRICITY TRANSITION - A SHORT SKETCH}

Debates about electricity transitions in Germany from the beginning have stressed two aspects: the use of renewable energy (RE) as a substitute for nuclear energy and fossil fuels and the decentralized architecture of a new system of electricity generation and supply [18]. Especially the second aspect continues to be one of a highly contentious character. Renewable energy can be harvested and run in a centralized manner by using big solar farms and vast (off shore) wind parks - administered, for example, by the established big energy providers or big investors. Many actors on the local level on the other hand, are mobilized by the idea that electricity generation should be dramatically decentralized in both technological as well as organizational ways and some form of local control should be re-established. This amounts to a transformation of the field of electricity generation and distribution

The following paragraphs briefly sketch the way this conflict has been played out over time in Germany.

\section{Phase One ( - 1998)}

The origins of the RE movement can be found mainly in the anti-nuclear power movement and to a lesser extent in protest movements against large big industry/government projects. Part of the movements were scientists, who were eager to develop alternatives to nuclear energy as well as many (organized) activists willing to build experimental installations. An important window of opportunity for these groups opened with the rising electoral successes of the Green party in the 1980 and 1990s, who were eager to pick up the energy question. In some communities with a strong Green support, local energy solutions were experimented with, operating with different organizational and technological mixes. The attitude of the incumbent energy providers as well as the government was outspokenly hostile. The energy providers by various means tried to block the feed in of renewable energies into the grid and the government provided only very limited support. With the help of working experiments RE actors over the 1990s nevertheless organized themselves in various associations, gained high public support and especially NGOs like Greenpeace and others lobbied intensively for RE. In a way it can be said that in this period local niches were formed, that, however, had little support or protection from the federal government. Spatially technological experimentation did take place mainly on the countryside especially in the case of wind mills, new organizational concepts were implemented in cities and bigger communities. The landscape orientation was a more general one: saving mother earth, saving planet earth were dominant frames and the immediate surroundings of sites were of minor importance.

\section{Phase Two (1998- 2008)}

The experiments became more meaningful, when a further window of opportunity opened in 1998 with the formation of a red-green coalition government on the federal level. Green politicians with experiences with local energy experiments entered the Parliament and a group around the Social Democratic Party of Germany solar activist Herman Scheer was successful in engineering a new regulatory framework for the RE. This helped to kick start a dynamic RE development and the formation of an ever broadening RE support coalition. Based on a high approval rate in the overall population, a quickly expanding RE industry formed, local and state governments became interested in RE not only because of its green credentials but also because of the economic benefits (new jobs, new taxes) that became to be associated with RE. Experiments became more widespread in these years and owing to the changes in the regulatory framework, the economics of the experiments became more calculable. The development nevertheless was driven by individual citizens or small groups of activists, who favored small installations. Landscape issues became of greater importance, because of the growing salience of economic aspects (select "suitable" sites) and the growing visibility of the RE installations across the countryside, which signaled that the natural environment is being put to new uses.

\section{Phase Three (2008 - 2012)}

Things turned nasty in phase three that started with the formation of the conservative-liberal coalition in 2008. The main developments were not directly linked to the formation of the new government but the 
way arising problems were addressed changed significantly. The liberal party from the beginning demanded that the support structure for the RE had to be dismantled. Even if they were not successful with this demand, it set the tone for the ensuing discussions. Instead of promoting RE, the government extended the running times of existing nuclear power plants. In addition, the support coalition for the RE began to crumble. The German RE industry suffered severely from cheap, mainly, Chinese imports. The bulk of the industry disappeared again and along with it the hopes of local and state politicians for economic rewards. This all led to regulatory amendments, which generally tried to make life for RE more difficult, especially for the small, decentralized units doing the experiments. Instead of support for small units, private households, farmers etc., bigger installations like off-shore wind and solar parks became the new beneficiaries. Experiments were now conducted in an environment that became increasingly hostile to the idea of experiments as transformative practice and which resulted in a growing sense of insecurity among the participants. In spite of the changing environment due to the time lag until which the changes were operating, this period showed a tremendous dynamic in the expansion of installations. Landscape issues were becoming of greater importance. On the one hand, the growth of installations was accompanied by debates about the proper landscape use and on the other hand, new regulations now favored large scale installations (off and on shore wind parks, solar parks), which contributed to a new form of industrializing the landscape.

\section{Phase Four 2012 - to Present}

After the Fukushima accident, the German government again changed its stance towards nuclear energy and decreed a phase out. This change of heart did not translate into more vigorous policies to promote RE. The government's intention to make RE growth more manageable had failed for several years. The government regularly had to upgrade projections, because the growth of installations was much quicker than anticipated. In phase four (starting with the formation of the Great Coalition in 2012) the system for supporting RE was changed again, in order to finally stop the quick expansion of RE and save the incumbent utilities. The new regulatory initiative - passed in 2014 - for the first time explicitly mandated upper limits for RE expansion. This was especially targeted at biomass and solar energy. Nevertheless, what had started as more or less isolated and unconnected experimentation in the 1980s and 1990s had now become an established part of a new system, which however is still in a phase of formation without a stable social structure. Along with this the preference for large scale installations in which the traditional actors in the electricity field were participating as well as new ones like investment funds, institutional investors are now becoming more important. This also increased landscape conflicts. Industrializing the landscape issues as well as local siting conflicts are becoming more common. In the 1990s challengers were battling the influence of "big" outside actors. At present (2018) local protest groups are again opposing siting plans of big outside actors, but this time it is about renewable energies.

\section{SITING CONFLICTS}

In the following, four cases of siting conflicts will be presented and analyzed. They were selected from a larger pool of case studies that have been performed within the scope of our aforementioned research efforts. The cases are not supposed to be "representative" in a statistical sense, nor are they "outlandish", because similar constellations can easily be found and added. Rather there is an attempt to show both the breadth of conflicts that can be found and which are typical for the German electricity transition as well as to hint at the practical problems linked with trying to influence such processes. Given the characteristics of electricity production and distribution in Germany, the capacity for steering action from above is limited and if executed might have to cope with serious obstacles. Trying to influence the transition necessitates to look at the specific cases very diligently and to be aware of the specific local constellations.

\section{Incorporation and Detachment}

The origins of energy related activities in the small community in the south west of Germany (case one) are linked to a citizen initiative, which formed in the late eighties after plans had been announced for 
the construction of a large composting plant. The citizen initiative opposing the construction of this plant eventually turned into a local party and in 1989 was able to win four out of eleven seats in the village council. Since alternatives to the composting plant had to be looked for, the citizen initiative was collecting information on biogas and biomass. In 1990, the citizen initiative turned local party was able to win the position of mayor. The central issue in the electoral campaign had been the composting plant. The mayor was building up contacts to a renowned expert in the field of bio-energy who quite accidentally lived in the same neighbourhood. These two persons closely cooperated in developing initial concepts for an installation. Out of this cooperation a core group came into existence, consisting of "respected" persons from the community and in spite of the fact that the political incumbents had lost elections over this issue, which understandably led to a certain uneasiness (up to 2012 the conservative party in the state of BadenWürttemberg was unchallenged in its leading political role), the community offered broad support. The core group consisted of the mayor, the mentioned bio-gas expert, the manager of a local company engaged in Photovoltaics (PV) and a representative of a local bank.

Once the plans had been approved, financial support from the EU and the state government was secured. At this point resistance in the community became organized and the creation of a new citizen initiative this time against the biomass installation was debated. The mayor and his core group could withstand the opposition especially by promoting openness, holding regularly meetings with the population, bringing in people from the outside, who stressed the lighthouse character of the plans. Later on farmers again voiced a protest against the installation. All this opposition activity, however, lacked a steady organization and people grouped around single issues for only a short period of time. The opponents furthermore did not link up to state wide or national organizations opposed to bioenergy or RE plans.

For the running of the installation, a dedicated organization was eventually founded which consisted of 60 partners (farmers, equipment producers, interested citizens etc.). Due to problems related to the complexity of the installation, the project, however, became soon merged with other "green" projects in the area, which then were all managed by a common board. The biomass installation in this case was the first of its kind in Germany with the official permit to ferment food remains. In spite of the fact that many observers call this installation the mother of all other similar installations in Germany, it was shut down in 2009. At this time, the installation provided electricity for $20 \%$ of all homes in the community. The community, however, was not willing to pay for the modernization of the installation, since new opposition had been formed. This opposition was mainly spurred by the growth of the installation and ensuing problems like lorry traffic etc. In addition, three meeting halls had been built to accommodate for the interest of the public in this model community and for holding meetings of bio-gas specialists, bio-gas associations, exhibitions etc.

Nevertheless, at this time the community was not any longer experimenting only with biomass. PV installations had spread in the community with the support of the aforementioned local company. In 2011, the community became the leading solar community in the state of Baden-Württemberg. In spite of the fact that larger PV installations were successfully opposed by local farmers, two windmills set up by groups of citizens were approved. The increasing production of energy proved difficult to manage, however. Up to 2011 a local network operator was responsible for the traffic and the continuous provision of energy locally and the export of not needed energy. Given the increasingly complex nature of the task and growing regulatory requirements for decentralized installations, the operator was forced to sell out to the regional oligopolist ENBW (one of the four big utilities in Germany). In spite of the constant struggles and resistance against individual projects a representative survey among the inhabitants of the community revealed that $88 \%$ of the population supported the overall line of development within the community and $87 \%$ claimed to be in favour of a further development of renewable energies.

This case is a prime (and typical) example of a community jumping early on the idea of renewable energies. The idea was driven forward by skilled individuals which achieved through determinate coalition building with various factions of the population a broad support within an environment that did not seem to be conducive to experiments: conservative and rural. The example also shows that the choice of technologies was more or less opportunistic. Not technology development and implementation as such was a determining factor, but the availability of different types of technologies supported by local expertise. 
Unlike in other communities, opposition against individual projects like a solar farm or the modernization of the biomass installation did not deroute the community from its path towards becoming $100 \%$ renewable. Opposition - like in many other cases - came from individual farmers, fearing increasing property prices that would damage their core business and from the population when it got the impression that things got too big and thus were damaging the promise of the project initiators to remain small and close to home.

The mechanism that we can observe in this case, is that people from outside the original field of electricity generation, which were active in previous non-related networks are organizing, uprooting the original field and eventually taking it over. The social practice as a whole has changed including the fields in which the practice is embedded as well as the landscape.

\section{Fusion and Hybridity: Windmills as an Ownership Conflict}

The siting conflict in our second case, situated in the state of Bavaria, plays out differently. Unlike in case one, activities to build windmills started at a much later date and were coming from outside actors. A project group specialized in wind energy development had established contacts with the state administration, which owns significant chunks of land in our community. The project developers contacted the local government, which sent signals of approval. Once the public was informed about the plans, serious opposition formed. The unifying slogan was that "our nature" should not be commercialized. The ongoing protests led to a more reluctant attitude of the local mayor and the local council towards the plans of the investors. The opposition against the wind park eventually split up in two groups. One group was aiming at building windmills at a different location within the community and was intending to have local control over the installations. The other group opposed the construction of all windmills in the community based on nature conservation arguments. The mayor and the city council eventually sided with the first group, an energy cooperative was set up and the first windmills were built. The success of the first group might be related to the fact that most of their supporters were longtime residents of the community and well organized and networked with the local establishment. The other group mainly consisted of individuals who had moved to the community more recently and were commuting to work in a nearby city. They had moved to the community because of its rural and peaceful character that now seemed to be alienated by the wind installations. The initially planned number of windmills by the way was not built. This was not the result of local opposition, but due to changing regulations on the state and federal level. At the beginning of the process, the state government in cooperation with project developers was supporting wind power development. Only two years later, the state government had put up regulations that brought wind development in Bavaria to a more or less complete halt. In addition federal regulations - as mentioned in our case one - were increasing requirements for the installation and running of windmills, which made it close to impossible for "amateurs" to run an installation and/or even apply for it. The involvement of lawyers, professionals and the cooperation with existing utilities and network operators was now required.

The mechanism that we observe in this case is the organization of opposition to a move from outside actors, which would disturb established practices and landscapes. Opposition tries to keep existing practices stable, but by attempting this, the social practice under siege, becomes transformed. The neighboring fields remain stable. A segment of one network is co-opted permanently into another previously separate network, thereby inducing an uneasy hybridization.

\section{Conflict Displacement: Biomass-Installation}

The electricity transition is not only about the growth of production facilities for renewable energies. The electricity transition also aims at a general decrease of electricity use and a more efficient use of electricity. One instrument to achieve these goals is electricity contracting. Companies, public authorities, big housing complexes are outsourcing electricity (and heat) supply to a third party, which guarantees that electricity will be provided and used more efficiently and more cheaply. The government once believed that this would be an important instrument to achieve its climate policy goals. Unfortunately, the market for these services has not developed and contracting remains a small activity. We will not discuss the reasons for this. Usually at any rate, it was not public protests or discussions, that prevented market development, because the public is not involved in such decisions and most of the time even is not aware 
of the fact that the mechanisms of energy provision change. We have studied one case, however, in which the contracting issue became linked to a siting conflict.

The town under consideration already had a long standing contracting relationship, which now needed to be renewed. The idea being that contracting should be done with the help of a local farmer and a newly built biomass installation at the outskirts of town. Once the decision became public, opposition formed. A variety of arguments were voiced, ranging from the industrialization of the landscape, traffic issues, smell, the questionable ecological value of biomass up to cost issues. It was argued that the decision making process lacked transparency and an insider deal had been made between the local council and the local farmer. The protesters organized an expertise, which demonstrated that other options than the proposed biomass installation would be cheaper. Upper levels of the public administration were contacted and organized pressure was exerted. The city council eventually cancelled the contract with the local farmer and signed a contract with an outside service provider, which used gas-fired equipment. Similar to the previous example the protest pitched long standing local residents against newcomers. Nevertheless, unlike in the previous example the "outside" protesters won. One important reasons for their success being that they already had experiences in organizing and fighting decisions by the local council. The same group of people had fought a decision for the procurement of a super market license. Insofar the group had experiences in organizing protest and could built on well-established forms of cooperation. This is also an important difference to the groups opposing RE-installations in case one and two, who failed to build up a consistent organizational effort to back their demands.

In this case, we find an established antagonism between social groups, which is also used to deal with conflicts in the electricity field. Established practices and landscapes remain stable.

\section{Grid Extension: Robust Action}

Another contested issue in the German electricity transition is the building of new cross-country grids. The official legitimation for these plans is that most of renewable energy is harvested in the North of Germany (off shore wind parks), but the energy is most wanted in the South of Germany. Electricity therefore has to be transported from the North to the South via a new powerful grid infrastructure. The rationale behind the grid extension plans has been put into doubt, but we are not concerned with these arguments, but rather with conflicts that were erupting along the planned new lines. Grid extension plans have been delayed due to local protests for years. What is behind these protests: a general aversion to grid extension and/or the official legitimation for the construction or local grievances?

The following remarks are based on research performed by Mario Neukirch in the Helmholtz Alliance project mentioned above [19]. Neukirch analyzed conflicts related to the Energy Line Extension Act (EnLAG) of 2009. The EnLAG is the federal grid capacity action plan. It foresaw the building of 24 power lines with a total length of $1.855 \mathrm{~km}$. Protest against the building of the new grid is unevenly distributed across the territory. Protest, however, successfully delayed the timely realization of the projects with most of them still under construction.

Within the project, all instances of significant opposition were analyzed in order to ascertain what actors participated in the protest and what aims were voiced. In contrast to the other cases studied important protest actors were always the local or district councils and local politicians from the majority parties. Furthermore, the analysis showed that most of the demands were oriented towards a slight reconfiguring of existing plans (the installation should be not close to residential housing areas, villages or whatever) or were aiming at the option to put cables underground. As a result, in most cases delays were recorded, but local solutions to the problems were found. Protest in this way was more like a NIMBY-phenomenon, but not directed against the electricity transition as a whole.

Just like in case two outside invaders are entering the field. Opposition begins to form, which is based on existing dominant networks and does not pursue the aim to change social practices. The primary focus is on a more benevolent social practice, which also leaves the existing landscape less changed 


\section{DISCUSSION AND CONCLUSION}

The aim of the paper was to show that protest events are not single-issue items but instead they are embedded in longer event chains. The highlighted protest instances also illustrate the point that in the German electricity transition there is not one clear-cut line of conflict, but various conflict lines are overlapping. In some cases in fact the overall outlook of the system of electricity production and distribution is at stake, in other cases the energy issue is used to prolong and re-fight existing conflicts, in still other cases we are mainly dealing with local grievances addressed to the far away authorities. Far from de-railing the electricity transition the conflicts also signal, that the transition has become part of everyday practices and conflicts. None of the conflicts studied is "representative" in any statistical sense, but they show the working of different mechanisms in the conflicts linked to the transition. The landscape issue e.g. is not a uniform one but plays out differently and is of varying importance in the individual constellations. Thus it is also obvious that the protest events have not been randomly selected, but with the aim in mind to highlight different protest constellations.

TABLE 2

\section{COMPARISON OF THE FOUR ANALYZED CASES}

\begin{tabular}{|l|l|l|l|l|}
\hline & Change agents & Temporal & Nature/Landscape & Field status \\
\hline Case one & Internal & $\begin{array}{l}\text { New long term } \\
\text { trajectory }\end{array}$ & "new" landscape & Transformation \\
\hline Case two & External & $\begin{array}{l}\text { Medium term } \\
\text { changes }\end{array}$ & $\begin{array}{l}\text { Partially re- } \\
\text { configured }\end{array}$ & Differentiation \\
\hline Case three & Internal & Decision oriented & Unchanged & Instability \\
\hline Case four & External & $\begin{array}{l}\text { Medium term } \\
\text { conflict }\end{array}$ & Put underground & Adaptation \\
\hline
\end{tabular}

\section{REFERENCES}

Cale, T., \& Kromer, M. (2015). Does proximity matter? Plant location, public awareness, and support for nuclear energy. The Social Science Journal, 52, 148-155.

Delicado, A., Junqueira, L., Fonseca, S., Truninger, M., Silva, L., Horta, A., \& Figueiredo, E. (2014). Not in anyone's backyard? Civil society attitudes towards wind power at the national and local levels in Portugal. Science \& Technology Studies, 27(2), 49-71.

Embirbayer, M. (1997). Manifesto for a relational sociology. American Journal of Sociology, 103, 281317.

Esaiasson, P. (2014). NIMBYism - A re-examination of the phenomenon. Social Science Research, 48, $185-195$.

Faller, F. (2016). A practice approach to study the spatial dimensions of the energy transition. Environmental Innovation and Societal Transitions, 19, 85-95.

Frantzeskaki, N., Kabisch, N., \& McPhearson, T. (2016). Advancing urban environmental governance: Understanding theories, practices and processes shaping urban sustainability and resilience. Environmental Science and Policy, 62, 1-6.

Fuchs, G. (Ed.). (2017). Lokale Impulse für Energieinnovationen. Bürgerwind, Contracting, KWK, Smart Grid. Wiesbaden: Springer.

Fuchs, G., \& Fettke, U. (2017). Incumbent-Challenger Interaktionen und die Veränderungen im Markt für Stromerzeugung und -verteilung in Deutschland. In S. Giacovelli (Hrsg.), Die Energiewende aus wirtschaftssoziologischer Perspektive. Theoretische Konzepte und empirische Zugänge (pp. 1544). Springer VS: Wiesbaden. 
Geels, F.W., Kern, F., Fuchs, G., Hinderer, N., Kungl, G., Mylan, J., . . Wassermann, S. (2016). The enactment of socio-technical transition pathways: A reformulated typology and a comparative multi-level analysis of the German and UK low-carbon electricity transitions (1990-2014). Research Policy, 45(4), 896-913.

Luhmann, N. (1995). Social systems. Redwood City: Stanford University Press.

Luhmann, N. (1998). Die Gesellschaft der Gesellschaft (2 vols.). Frankfurt a.M: Suhrkamp.

Marx, K. (1977). Capital, vol. 1. Translated by Ben Fowkes. New York: Vintage Books.

Marx, K., \& Engels, F. (1978). The Marx-Engels Reader (2d Ed.). Edited by Robert C. Tucker. New York: Norton.

McAdam, D., \& Boudet, H.S. (2012). Putting social movements in their place: Explaining opposition to energy projects in the United States. 2000-2005. Cambridge: Cambridge University Press

Neukirch, M. (2016). Protests against German electricity grid extension as a new social movement? A journey into the areas of conflict. Energy, Sustainability and Society, 6(4).

Parsons, T. (1951). The social system. Glencoe, Ill: Free Press.

Simmel, G. (1950). The sociology of Georg Simmel. Glencoe, Ill: Free Press.

Watts, D.J. (1999). Small worlds: The dynamics of networks between order and randomness. Princeton: Princeton University Press.

Weber, M. (1978). Economy and society. An outline of interpretive sociology (2 vols.). Berkeley: University of California Press. 